\title{
Comunicação
}

[Communication]

\section{Hemencyrtus herbertii Ashmead (Hymenoptera: Encyrtidae) como parasitóides de dípteros muscóides coletados em Itumbiara, Goiás}

\author{
[Hemencyrtus herbertii Ashmead (Hymenoptera: Encyrtidae) as parasitoid of muscoids dipterous collected in \\ Itumbiara Goiás, Brazil] \\ C.H. Marchiori, O.M. Silva Filho, L.A. Pereira, L.C.S. Ribeiro, V.R. Borges \\ ${ }^{1}$ Departamento de Biologia \\ Instituto Luterano de Ensino Superior de Itumbiara ILES-ULBRA \\ Caixa Postal 23-T \\ 75500-000 - Itumbiara, GO
}

\begin{abstract}
Algumas espécies de moscas são de fundamental importância médica e veterinária, uma vez que podem produzir miíases e atuar na veiculação de patógenos ao homem e aos animais (Chow, 1940; Greenberg, 1971). Elas têm sido encontradas veiculando mais de 100 espécies de organismos causadores de doenças como bactérias, protozoários e helmintos (Greenberg, 1971). Além dos inseticidas, também podem ser usados como controle dos insetos os chamados reguladores naturais tanto na agricultura como em áreas de criação animal (Silveira et al., 1989). Alguns autores acreditam ser necessário pesquisar novas metodologias que visem o controle das moscas (Mendes e Linhares, 1993).
\end{abstract}

Muitos gêneros de Encyrtidae apresentam reprodução poliembriônica, isto é, com muitos parasitóides emergindo de um único hospedeiro (Grissell e Schauff, 1990). Várias espécies dessa família têm sido utilizadas com sucesso em programas de controle biológico. Hemencyrtus herbertii Ashmead (Hymenoptera: Encyrtidae) comporta-se como parasitóide de larvas, desenvolvendo-se internamente no corpo do hospedeiro e emergindo do pupário (Noyes, 1980; Gauld e Bolton, 1988).

O objetivo desta pesquisa foi ampliar o conhecimento da biologia do parasitóide $H$. herbertii no Brasil.
O estudo foi realizado na Faculdade de Agronomia, localizada no município de Itumbiara-GO $\left(18^{\circ} 25^{\prime} \mathrm{S}-49^{\circ} 13^{\prime} \mathrm{W}\right)$. Procedeuse à coleta de adultos de moscas por meio de armadilhas construídas com lata de coloração preta fosca, medindo cerca de $19 \mathrm{~cm}$ de altura por $9 \mathrm{~cm}$ de diâmetro, com duas aberturas tipo venezianas, localizadas no terço inferior, para permitir a entrada dos insetos. Na parte superior das latas foram acoplados funis de nylon, abertos nas extremidades, com bases voltadas para baixo e envolvidos em sacos plásticos cuja remoção permitiu a coleta das moscas.

Serviram como iscas para atração das moscas, rins de bovino, fezes humanas, vísceras de frango e fígado bovino depositados no interior das latas, sobre uma camada de terra. Utilizaramse cinco armadilhas, penduradas em árvores de eucalipto (Eucalyptus sp.) a um metro do solo, a dois metros uma das outras e a 50 metros do lixo doméstico. Os indivíduos coletados foram levados para o laboratório, sacrificados com éter etílico e conservados em álcool $70 \%$ para posterior identificação. Para a obtenção dos parasitóides, o conteúdo das armadilhas foi colocado em recipientes plásticos contendo uma camada de areia para servir de substrato à pupação das larvas.

Peneirada a areia (após 15 dias de sua colocação

Recebido para publicação em 25 de novembro de 2003

Recebido para publicação, após modificações, em 25 de abril de 2004

E-mail: pesquisa.itb@ulbra.br 
no campo), dela se extraíram as pupas, posteriormente colocadas, individualmente, em cápsulas de gelatina (número 00), para a obtenção de moscas e/ou parasitóides. A preferência dos espécimes de $H$. herbertii pelos substratos e pelos seus hospedeiros foi testada pelo qui-quadrado, ao nível de $5,0 \%$ de probabilidade.

No período de março de 2001 a abril de 2002, coletaram-se 511 pupas de Diptera e 121 espécimes de Hemencyrtus herbertii em três substratos diferentes. A prevalência total de parasitismo observada foi de 3,5\% (18/511; Tab. 1). Frango foi o substrato que atraiu maior número de $H$. herbertii, $61,9 \%$ dos indivíduos coletados, e a maior prevalência de parasitismo, $2,3 \%$. Provavelmente, a alta prevalência de parasitismo foi influenciada pelas variações na qualidade e disponibilidade de recursos, pela densidade dos hospedeiros e pelo comportamento gregário do parasitóide.

Tabela 1. Hemencyrtus herbertii coletados no período de março de 2001 a abril de 2002 em Itumbiara, Goiás

\begin{tabular}{lcccc}
\hline Isca/ Grupo taxonômico & Número de indivíduos & $\begin{array}{c}\text { Freqüência de } \\
\text { Hemencyrtus herbertii }\end{array}$ & $\begin{array}{c}\mathrm{N}^{\mathbf{0}} \text { de pupas } \\
\text { parasitadas }\end{array}$ & $\begin{array}{c}\text { Prevalência } \\
\text { Vísceras de frango: }\end{array}$ \\
$\begin{array}{l}\text { Hemilucilia flavifacies } \\
\text { Peckia chrysostoma }\end{array}$ & 16 & 14 & 3 & 18,8 \\
Fezes humanas: & 280 & 61 & 9 & 3,2 \\
Musca domestica & 20 & 5 & 1 & 5,0 \\
Oxysarcodexia thornax & 109 & 18 & 2 & 1,8 \\
Fígado bovino: & 31 & 3 & 1 & 3,2 \\
Euboettcheria collusor & 55 & 20 & 2 & 3,6 \\
Synthesiomyia nudiseta & & & & \\
\hline
\end{tabular}

Segundo Noyes (1980) e Gauld e Bolton (1988), $H$. herbertii comporta-se como parasitóide gregário, desenvolvendo internamente no corpo do hospedeiro e emergindo do pupário.

Em relação aos substratos, $H$. herbertii apresentou preferência por fezes humanas $\left(\lambda^{2}=2196,42 ; \mathrm{GL}: 24 ; \mathrm{P}<0,05\right)$. Com relação as hospedeiros, Hemencyrtus sp. apresentou preferência por pupas de Oxysarcodexia thornax Walker (Diptera: Sarcopphagidae).

A utilização dos reguladores naturais como os parasitóides pode ser uma alternativa no controle de moscas sinantrópicas.

Palavras-chave: controle biológico, mosca, parasitóide, hospedeiro, Hymenoptera

\section{ABSTRACT}

This study determined the species of hosts of the parasitoid Hemencyrtus herbertii Ashmead (Hymenoptera: Encyrtidae) in human feces, cattle liver and chicken viscera, collected in Itumbiara, Goias. The pupae were obtained by the flotation method. They were individually placed in gelatin capsules until the emergence of adult flies or their parasitoids. The overall prevalence of parasitism was $23.7 \%$.

Keywords: biocontrol, fly, parasitoid, host, Hymenoptera 


\section{REFERÊNCIAS BIBLIOGRÁFICAS}

CHOW, C.Y. The commom blue bottle fly Chrysomya megacephala as a carrier of pathogenic bacteria in Beijing. Chi. Chin. Med., v.57, p.145-153, 1940.

GAULD, I.D.; BOLTON, B. The Hymenoptera. Oxford: Oxford University, 1988. 331p.

GREENBERG, B. Flies and disease - ecology, classification and biotic association. New Jersey: Princeton University, 1971. 856p.

GRISSELL, E.E.; SCHAUF, M.E. A handbook of the families of Nearctic Chalcidoidea (Hymenoptera). Entomol. Soc. Was., v.2, p.1-86,
1990.

MENDES, J.; LINHARES, A.X. Atratividade por iscas, sazonalidade e desenvolvimento ovariano em várias espécies de Muscidae (Diptera). Rev. Bras. Entomol., v.37, p.289-297, 1993.

NOYES, J.S. A review of genera of Neotropical Encyrtidae (Hymenoptera: Chalcidoidea). Entomol. Ser., v.41, p.1-253, 1980.

SILVEIRA， G.A.R.; MADEIRA， N.G.; AZEREDO-ESPIN, A.M.L. Levantamento de microhimenóptera parasitóides de dípteros de importância médico-veterinária no Brasil. Mem. Inst. Oswaldo Cruz, v.84, p.505-510, 1989. 